\title{
Penerapan model Group Investigation (GI) dalam pembelajaran analisis kasus pelanggaran Undang-Undang ITE
}

\author{
Elizamiharti Elizamiharti ${ }^{1}$, Restyaliza Dhini Hary ${ }^{2}$, Muhammad Reza Hasibuan ${ }^{3}$ \\ ${ }^{123}$ Program Studi Sistem Informasi, STMIK Indonesia Padang
}

\begin{abstract}
This study aims to determine the effect of applying the Group Investi-gation (GI) model in learning to analyze cases of violations of the ITE Law at the Professional Ethics Course at STMIK Indonesia Padang. This type of research is quantitative research with descriptive analytical methods. The type of research design used is a pre-experimental design with pre-test and post-test designs. The data in this study are scores obtained by students in learning to analyze cases of violations of ITE law in the Professional Ethics Course at STMIK Indonesia Padang from the results of tests before and after using the Group Investiation learning model. The results of these tests were compared using the t-test formula to determine whether or not the effect occurred. The results of this study indicate that the GI model can improve the ability of students to analyze cases of violations of ITE law in the Professional Ethics Course at STMIK Indonesia Padang.
\end{abstract}

Keywords: Case analysis, violations, ITE law, group investigation (GI)

\section{PENDAHULUAN}

Perkembangan sains dan teknologi telah menyebabkan pelbagai perubahan kehidupan di bidang politik, ekonomi, sosial, dan budaya. Salah satu perkembangan sains dan teknologi yang melaju dengan pesat adalah perkembangan di bidang teknologi informasi. Dengan adanya teknologi informasi, masyarakat diberi kemudahan untuk melakukan komunikasi dan bertukar informasi melalui sarana yang berupa internet. Melalui internet, pertukaran informasi berlangsung dengan lebih cepat dan semakin pesat. Namun, internet juga dapat memberikan peluang terhadap perlanggaran hukum di ranah teknologi informasi, seperti tindakan pencemaran nama baik melalui akun-akun media sosial, pemalsuan, penipuan, dan tindak kejahatan lain yang dapat merugikan orang lain.

Di Indonesia, internet memiliki pertumbuhan dan perkembangan yang sangat pesat. Walaupun persentase sebaran dan penetrasi populasi internet masih rendah, namun negara Indonesia merupakan salah satu negara dengan jumlah pengguna internet terbesar di Asia Tenggara (Atmaja, 2014). Untuk mewaspadai pengaruh penggunaan teknologi internet yang jumlah penggunanya sangat pesat, pemerintah Indonesia melalui Kementerian Komunikasi dan Informatika menyiapkan sejumlah peraturan untuk mengatur beragam jenis dan model informasi. Salah satunya adalah Undang-Undang Republik Indonesia Nomor 11 Tahun 2008 tentang Informasi dan Transaksi Elektronik (UU ITE). UU ITE menjadi pertanda berubahnya orientasi, model, dan sistem informasi di Indonesia, serta menandai kembalinya pembatasan negara atas informasi, termasuk informasi yang diterima melalui internet.

Untuk menghindari perilaku yang diatur dan dilarang UU ITE, maka masyarakat pengguna internet, termasuk Mahasiswa Jurusan Sistem Informasi diwajibkan belajar dari kasus-kasus yang terjadi di internet maupun media sosial. Melalui proses belajar, mahasiswa dapat memperoleh pelajaran bahwa UU ITE tidak berniat membatasi ruang gerak berinternet, tetapi dapat menjadi rambu-rambu di dalam penggunaannya. Oleh karena itu, materi tentang UU ITE menjadi hal penting yang harus termuat dalam kurikulum pembelajaran, 
khususnya bagi Mahasiswa Jurusan Sistem Informasi yang merupakan cikal bakal penerus dan pengembang teknologi informasi.

Mahasiswa Jurusan Sistem Informasi selayaknya telah mampu dan terampil dalam menganalisis kasus pelanggaran UU ITE. Namun, pada kenyataannya keterampilan mahasiswa dalam menganalisis kasus pelanggaran UU ITE di STMIK Indonesia Padang masih rendah. Hal ini dapat dibuktikan dengan rendahnya nilai rata-rata yang diperoleh mahasiswa dalam pembelajaran menganalisis kasus pelanggaran UU ITE.

Berdasarkan hasil pengalaman mengajar dalam Mata Kuliah Etika Profesi dan hasil wawancara dengan mahasiswa, dapat diketahui bahwa penyebab rendahnya kemampuan mahasiswa dalam menganalisis kasuskasus pelanggaran UU ITE disebabkan karena sebagian besar mahasiswa kurang menyukai materi pembelajaran yang berkaitan dengan peraturan dan perundang-undangan, khususnya pembelajaran tentang UU ITE. Selain itu, juga diketahui bahwa banyak mahasiswa yang tidak mengetahui tentang UU ITE, hanya beberapa yang pernah mendengar, dan hanya mengetahui bahwa UU ITE itu adalah sebatas sebuah peraturan tentang informasi dan transaksi elektronik. Hal lain yang menyebabkan rendahnya kemampuan mahasiswa dalam menganalisis kasuskasus pelanggaran UU ITE adalah kurangnya motivasi dari diri mahasiswa untuk mengikuti pembelajaran tentang UU ITE.

Setelah diadakan wawancara lebih lanjut dengan mahasiswa, dapat diketahui bahwa penyebab rendahnya motivasi belajar mahasiswa yang berdampak pada rendahnya hasil belajar mahasiswa dalam menganalisis kasus-kasus pelanggaran UU ITE adalah dikarenakan cara belajar atau model pembelajaran yang diterapkan dalam pembelajaran menganalisis kasus pelanggaran UU ITE kurang menarik perhatian mahasiswa. Dari hasil wawancara, juga dapat diketahui bahwa mahasiswa merasa bosan atau jenuh dalam belajar karena pada saat pembelajaran, kegiatan hanya meliputi penjelasan tentang UU ITE kemudian mahasiswa ditugaskan untuk membaca sebuah kasus dan mengaitkannya dengan undang-undang tanpa adanya kegiatan tanya jawab atau diskusi mendalam dengan sesama teman untuk membahas persoalan dalam kasus pelanggaran UU ITE.

Berdasarkan catatan lapangan, dapat diketahui bahwa model pembelajaran yang telah diterapkan dosen dalam pembelajaran menganalisis kasus pelanggaran UU ITE masih tergolong kurang efektif, sebab dalam pelaksanaannya dosen hanya menjelaskan materi dengan model ceramah, kemudian dilanjutkan dengan kegiatan penugasan dan tanya jawab. Dengan model pembelajaran seperti ini, tentunya kemampuan mahasiswa dalam hal bersosialisasi dan berpikir kritis akan sulit dikembangkan. Padahal, melalui pembelajaran menganalisis kasus inilah kemampuan mahasiswa dalam hal bersosialisasi dan kemampuan berpikir kritis mahasiswa dapat lebih dikembangkan karena dalam menganalisis sejumlah kasus pelanggaran UU ITE terdapat sejumlah persoalan kehidupan sosial yang terkait dengan penggunaan dan perkembangan teknologi informasi yang dapat dibahas mahasiswa secara bersama-sama.

Untuk menghadapi persoalan tersebut, maka perlu diterapkan sebuah model pembelajaran yang mampu memotivasi dan meningkatkan kemampuan mahasiswa dalam menganalisis kasus-kasus pelanggaran UU ITE, yaitu melalui penggunaan model pembelajaran yang inovatif. Salah satu model pembelajaran yang dapat diterapkan adalah model pembelajaran Group Investigation (GI). Model pembelajaran GI merupakan salah satu bentuk pembelajaran kooperatif, yaitu model pembelajaran dengan kelompok kecil yang membantu mahasiswa dalam meningkatkan prestasi akademik dan hubungan sosialnya. Model pembelajaran GI menuntut mahasiswa untuk memiliki kemampuan dalam berkomunikasi dan keterampilan proses berkelompok (group process skills). Dengan model pembelajaran ini, para mahasiswa dapat membuat kemajuan besar ke arah pengembangan sikap, nilai, dan tingkah laku yang memungkinkan mereka dapat berpartisipasi dalam komunitas mereka dengan caracara yang sesuai dengan tujuan pendidikan. Dalam hal ini, pengetahuan mahasiswa tidak hanya diperoleh dari dosennya, tetapi juga dari hasil belajar kelompok dengan temannya. Dengan berkelompok, seorang mahasiswa dapat memberikan kesempatan kepada teman yang lain untuk mengemukakan pendapatnya dengan cara menghargai pendapat orang lain, saling mengoreksi, dan saling membetulkan sama lainnya.

Penelitian-penelitian sebelumnya mengenai penggunaan model pembelajaran GI telah dilakukan oleh beberapa orang. Di antaranya (Perwitasari, Sumarmi, \& Amirudin, 2016) yang telah melakukan penelitian dengan judul "Pengaruh Group Investigation Berbasis Outdoor Study terhadap Kemampuan Berpikir Analitis Siswa". Hasil penelitian mereka menunjukkan adanya pengaruh positif dari penggunaan GI dalam proses belajar mengajar terhadap hasil belajar mahasiswa. mahasiswa dari kelas pembelajaran model Group Investigation menunjukkan mereka lebih kooperatif dan mementingkan kepentingan orang lain, bahkan ketika berinteraksi dengan mahasiswa di luar kelompok atau dalam situasi di luar kelas. Tidak hanya itu, mereka pun dapat mengekspresikan diri sendiri, kemandirian dan tanggung jawab ketika mendapat tugas dalam kelompok (Perwitasari et al., 2016). Selain itu, (Wijayanti, Sumarmi, \& Amirudin, 2016) juga telah melakukan penelitian yang berjudul "Perbandingan Model Group Investigation dengan Problem Based Learning Berbasis Multiple Intelligence terhadap Kemampuan Memecahkan Masalah mahasiswa SMA” dengan hasil penelitiannya yang menunjukkan bahwa model pembelajaran GI lebih mendorong mahasiswa dalam meningkatkan hasil belajar 
kognitif (Wijayanti et al., 2016). Hal ini dikarenakan pembelajaran dengan model GI dapat membuat mahasiswa menjadi terfokus mengikuti proses pembelajaran dan saling bekerja sama, serta dapat meningkatkan interaksi antara mahasiswa dan guru.

Berdasarkan permasalahan yang telah dikemukakan, peneliti bermaksud mengadakan penelitian yang bertujuan untuk mengetahui pengaruh penerapan model pembelajaran GI dalam pembelajaran menganalisis kasus pelanggaran UU ITE pada Mata Kuliah Etika Profesi Mahasiswa Program Studi Sistem Informasi STMIK Indonesia Padang. Oleh karena itu, penelitian yang berjudul "Penerapan Model Group Investigation (GI) dalam Pembelajaran Analisis Kasus Pelanggaran Undang-Undang ITE pada Mata Kuliah Etika Profesi” penting untuk dilaksanakan.

\section{METODE}

Metode penelitian yang digunakan dalam penelitian ini adalah metode deksriptif analitis. Penelitian ini dikatakan menggunakan metode deskriptif analitis karena penelitian ini bertujuan untuk mendeskripsikan kemampuan mahasiswa dalam menganalisis kasus pelanggaran UU ITE Mata Kuliah Etika Profesi di STMIK Indonesia Padang sebelum dan setelah menggunakan model GI, serta menganalisis ada atau tidak pengaruh penerapan model GI terhadap kemampuan menganalisis kasus pelanggaran UU ITE.

Jenis rancangan yang digunakan dalam penelitian ini adalah rancangan pra-eksperimental dengan bentuk rancangan prates dan pascates. Rancangan pra-eksperimental dengan bentuk rancangan prates (tes awal) dan pascates (tes akhir) ini digunakan untuk mengungkapkan hubungan sebab-akibat hanya dengan cara melibatkan satu kelompok subjek saja. Suatu kelompok sebelum dikenai perlakuan tertentu diberi prates, kemudian setelah perlakuan diberikan, dilakukan pengukuran lagi untuk mengetahui akibat dari perlakuan itu. Pengujian sebabakibat dilakukan dengan cara membandingkan hasil prates dengan hasil pascates. Subjek penelitian ini adalah Mahasiswa STMIK Indonesia Padang. Objek penelitian ini adalah pembelajaran analisis kasus pelanggaran UU ITE pada Mata Kuliah Etika Profesi. Lokasi penelitian adalah di STMIK Indonesia Padang. Instrumen yang digunakan untuk pengumpulan data dalam penelitian ini adalah tes. Data yang dikumpulkan dalam penelitian ini adalah skor kemampuan mahasiswa dalam menganalisis kasus pelanggaran UU ITE. Pengumpulan data dilakukan dengan melakukan pertemuan sebanyak 3 (tiga) kali tatap muka. Pengumpulan data hasil tes kemampuan mahasiswa dalam menganalisis kasus pelanggaran UU ITE tersebut dilakukan dengan langkahlangkah sebagai berikut. Pertama, dilakukan proses menganalisis kasus pelanggaran UU ITE kepada mahasiswa tanpa menggunakan model pembelajaran GI pada pertemuan pertama. Mahasiswa diminta untuk memahami UU ITE dan membaca sebuah kasus yang berkaitan dengan pelanggaran UU ITE, kemudian mahasiswa diminta untuk mengerjakan tes awal (prates). Setelah selesai, lembaran kerja mahasiswa dikumpul untuk diberikan penilaian. Kedua, dilakukan proses pembelajaran menganalisis kasus pelanggaran UU ITE kepada mahasiswa dengan menggunakan model GI (sesuai dengan tahap pelaksanaan dalam prosedur penelitian) pada pertemuan kedua. Pada langkah ini, mahasiswa hanya mengikuti proses pembelajaran dan dosen tidak memberikan tes diakhir pelajaran.

Data yang diperolehselanjutnya dianalisis melalui langkah-langkah berikut. Pertama, memeriksa hasil pekerjaan mahasiswa. Kedua, memberi skor hasil tes yang telah dilakukan mahasiswa. Ketiga, mengolah skor menjadi nilai. Keempat, menentukan nilai rata-rata hitung. Kelima, menafsirkan hasil belajar mahasiswa berdasarkan rata-rata hitung dan nilai ketuntasan minimum. Keenam, mengklasifikasikan hasil prates dan hasil pascates kemampuan mahasiswa dalam menganalisis kasus pelanggaran UU ITE berdasarkan skala 10. Ketujuh, membuat diagram batang mengenai kemampuan mahasiswa dalam menganalisis kasus pelanggaran UU ITE. Kedelapan, melakukan uji normalitas dan homogenitas data. Kesembilan, melakukan pengujian hipotesis untuk melihat pengaruh model GI terhadap kemampuan mahasiswa dalam menganalisis kasus pelanggaran UU ITE. Kesepuluh, menyimpulkan hasil analisis data dan pembahasan.

\section{HASIL DAN PEMBAHASAN}

Kemampuan mahasiswa dalam menganalisis kasus pelangaran UU ITE sebelum dan setelah menggunakan model GI dapat diketahui dengan cara mengubah skor prates dan pascates menjadi nilai, kemudian menghitung nilai rata-rata kemampuan mahasiswa dalam menganalisis kasus pelangaran UU ITE sesuai dengan rumus yang terdapat dalam Bab 3. Berikut hasil analisis terhadap skor kemampuan mahasiswa dalam menganalisis kasus pelangaran UU ITE sebelum dan setelah menggunakan model GI. 
Kemampuan Mahasiswa dalam Menganalisis Kasus Pelangaran UU ITE sebelum Menggunakan Model Group Investigation

Berdasarkan hasil analisis terhadap skor prates yang diperoleh siswa, kemampuan mahasiswa dalam menganalisis kasus pelangaran UU ITE sebelum model GI dapat dilihat pada Tabel 1.

Tabel 1.

Kemampuan Mahasiswa Menganalisis Kasus Pelangaran UU ITE sebelum Menggunakan Model Group Investigation

\begin{tabular}{|c|c|c|c|c|}
\hline & Kode Sampel & Skor & Nilai & Kualifikasi \\
\hline 1 & KS01 & 41 & 47,13 & Hampir Cukup \\
\hline 2 & KSO2 & 66 & 75,86 & Lebih dari Cukup \\
\hline 3 & KS03 & 46,5 & 53,45 & Hampir Cukup \\
\hline 4 & KS04 & 52 & 59,77 & Cukup \\
\hline 5 & KS05 & 56 & 64,37 & Cukup \\
\hline 6 & KS06 & 45,5 & 52,30 & Hampir Cukup \\
\hline 7 & KS07 & 54 & 62,07 & Cukup \\
\hline 8 & KS08 & 54 & 62,07 & Cukup \\
\hline 9 & KS09 & 64,5 & 74,14 & Lebih dari Cukup \\
\hline 10 & KS10 & 49 & 56,32 & Cukup \\
\hline 11 & KS11 & 46 & 52,87 & Hampir Cukup \\
\hline 12 & KS12 & 47 & 54,02 & Hampir Cukup \\
\hline 13 & KS13 & 53,5 & 61,49 & Cukup \\
\hline 14 & KS14 & 61,5 & 70,69 & Lebih dari Cukup \\
\hline 15 & KS15 & 44 & 50,57 & Hampir Cukup \\
\hline 16 & KS16 & 43 & 49,43 & Hampir Cukup \\
\hline 17 & KS17 & 44 & 50,58 & Hampir Cukup \\
\hline 18 & KS18 & 61,5 & 70,69 & Lebih dari Cukup \\
\hline 19 & KS19 & 52 & 59,77 & Cukup \\
\hline 20 & KS20 & 42 & 48,26 & Hampir Cukup \\
\hline 21 & KS21 & 52 & 59,77 & Cukup \\
\hline 22 & KS22 & 36 & 41,38 & Kurang \\
\hline 23 & KS23 & 37 & 42,53 & Kurang \\
\hline 24 & KS24 & 50 & 57,47 & Cukup \\
\hline 25 & KS25 & 51 & 58,62 & Cukup \\
\hline 26 & KS26 & 59 & 67,82 & Lebih dari Cukup \\
\hline 27 & KS27 & 53 & 60,92 & Cukup \\
\hline 28 & KS28 & 55,5 & 63,79 & Cukup \\
\hline 29 & KS29 & 68 & 78,16 & Baik \\
\hline 30 & KS30 & 45 & 51,72 & Hampir Cukup \\
\hline 31 & KS31 & 42 & 48,28 & Hampir Cukup \\
\hline & $\begin{array}{c}\text { Jumlah } \\
\text { Rata-Rata }\end{array}$ & & $\begin{array}{l}\mathbf{6 6 , 3 1} \\
58,27\end{array}$ & Cukup \\
\hline
\end{tabular}

Berdasarkan skor yang diperoleh dari 31 orang mahasiswa pada tes awal (prates), jumlah nilai yang diperoleh mahasiswa sebelum menggunakan model GI adalah 1806,31 dengan nilai rata-rata 58,27. Selanjutnya, data digambarkan dalam bentuk tabel rentangan nilai, kualifikasi, frekuensi, dan persentase sebagaimana Tabel 2.

Berdasarkan data pada Tabel 2, diperoleh gambaran kemampuan mahasiswa dalam menganalisis kasus pelangaran UU ITE sebelum menggunakan model GI sebagai berikut. Pertama, mahasiswa yang memperoleh nilai dengan kualifikasi Baik (B) berjumlah 1 orang $(3,23 \%)$. Kedua, mahasiswa yang memperoleh nilai dengan kualifikasi Lebih dari Cukup (LdC) berjumlah 5 orang $(16,13 \%)$. Ketiga, mahasiswa yang memperoleh nilai dengan kualifikasi Cukup (C) berjumlah 12 orang $(38,71 \%)$. Keempat, mahasiswa yang memperoleh nilai dengan kualifikasi Hampir Cukup (HC) berjumlah 11 orang $(35,48 \%)$. Kelima, mahasiswa yang memperoleh nilai dengan kualifikasi Kurang (K) berjumlah 2 orang $(6,45 \%)$. Selanjutnya, data kemampuan mahasiswa dalam menganalisis kasus pelangaran UU ITE sebelum menggunakan model GI dideskripsikan dalam bentuk diagram batang sebagaimana yang terlihat pada Gambar 1 . 
Tabel 2.

Rentangan Nilai, Kualifikasi, Frekuensi, dan Persentase Kemampuan Mahasiswa sebelum Menggunakan Model Group Investigation

\begin{tabular}{ccccc}
\hline No & Rentangan Nilai & Kualifikasi & Frekuensi & Persentase (\%) \\
\hline 1 & $96-100$ & Sempurna & 0 & 0 \\
2 & $86-95$ & Baik Sekali & 0 & 0 \\
3 & $76-85$ & Baik & 1 & 3,23 \\
4 & $66-75$ & Lebih dari Cukup & 5 & 16,13 \\
5 & $56-65$ & Cukup & 12 & 38,71 \\
6 & $46-55$ & Hampir Cukup & 11 & 35,48 \\
7 & $36-45$ & Kurang & 2 & 6,45 \\
8 & $26-35$ & Kurang Sekali & 0 & 0 \\
9 & $16-25$ & Buruk & 0 & 0,00 \\
10 & $0-15$ & Buruk Sekali & 0 & 0,00 \\
\hline & & & $\mathbf{3 1}$ & $\mathbf{1 0 0}$ \\
\hline
\end{tabular}

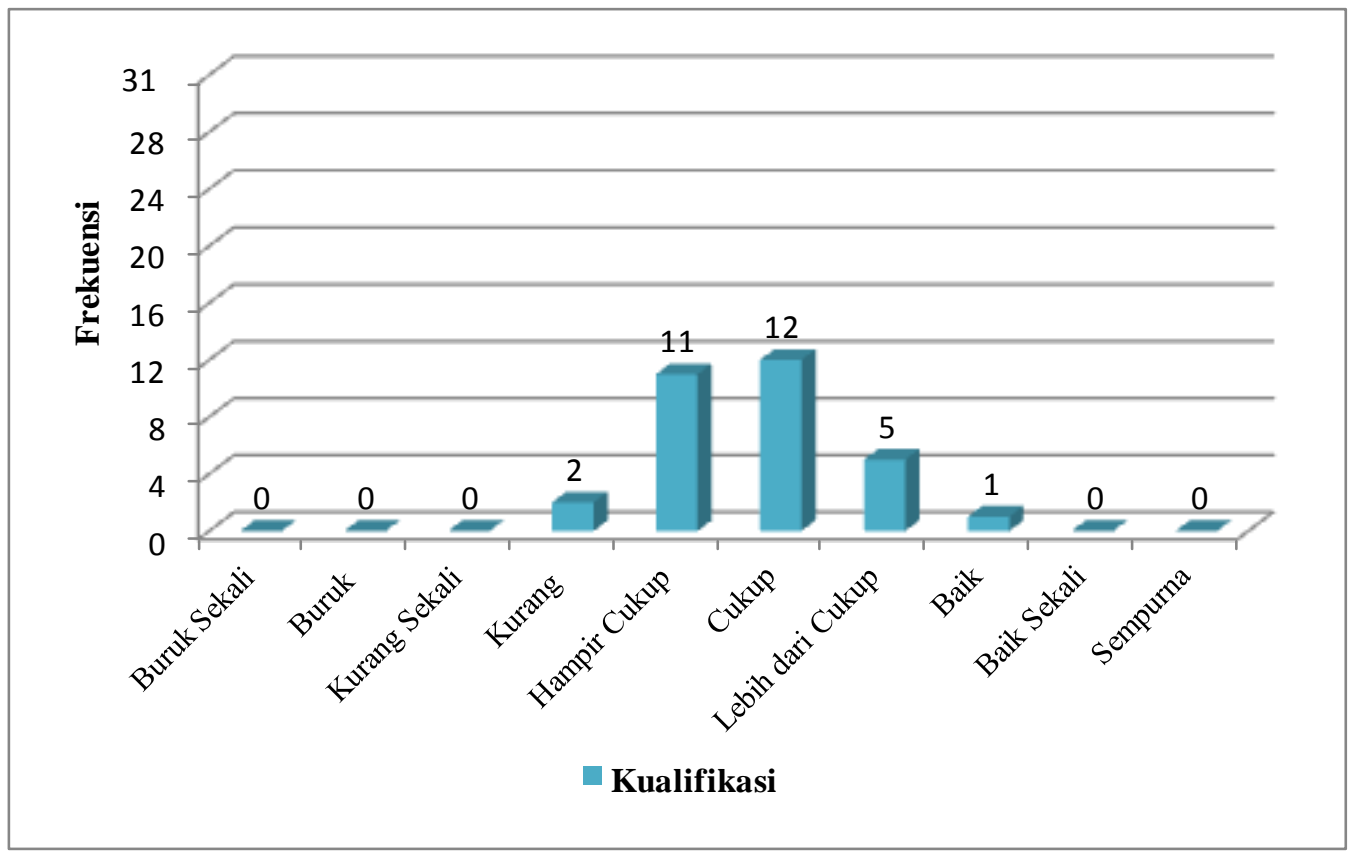

Gambar 1. Diagram Batang Kemampuan Mahasiswa dalam Menganalisis Kasus Pelangaran UU ITE sebelum Menggunakan Model Group Investigation

Kemampuan Mahasiswa dalam Menganalisis Kasus Pelangaran UU ITE setelah Menggunakan Model Group Investigation

Berdasarkan hasil analisis terhadap skor pascates yang diperoleh siswa, kemampuan mahasiswa dalam menganalisis kasus pelangaran UU ITE sebelum model GI dapat dilihat pada Tabel 3.

Berdasarkan tabel 3 skor yang diperoleh 31 orang mahasiswa pada tes akhir (pascates), jumlah nilai kemampuan mahasiswa dalam menganalisis kasus pelangaran UU ITE setelah model GI adalah 2394,28 dengan nilai rata-rata 77,23. Selanjutnya, data digambarkan dalam bentuk tabel rentangan nilai, kualifikasi, frekuensi, dan persentase sebagaimana Tabel 4. 
Tabel 3.

Kemampuan Mahasiswa Menganalisis Kasus Pelangaran UU ITEsetelah Menggunakan Model Group Investigation

\begin{tabular}{ccccc}
\hline No & Kode Sampel & Skor & Nilai & Kualifikasi \\
\hline $\mathbf{1}$ & $\mathbf{2}$ & $\mathbf{3}$ & $\mathbf{4}$ & $\mathbf{5}$ \\
1 & KS01 & 71 & 81,61 & Baik \\
2 & KS02 & 75 & 86,21 & Baik Sekali \\
3 & KS03 & 65,5 & 75,29 & Lebih dari Cukup \\
4 & KS04 & 63 & 72,41 & Lebih dari Cukup \\
5 & KS05 & 73,5 & 84,48 & Baik \\
6 & KS06 & 61,5 & 70,69 & Lebih dari Cukup \\
7 & KS07 & 43 & 49,43 & Hampir Cukup \\
8 & KS08 & 76 & 87,36 & Baik Sekali \\
9 & KS09 & 78 & 89,66 & Baik Sekali \\
10 & KS10 & 65,5 & 75,29 & Lebih dari Cukup \\
11 & KS11 & 61 & 70,11 & Lebih dari Cukup \\
12 & KS12 & 61 & 70,11 & Lebih dari cukup \\
13 & KS13 & 68,5 & 78,74 & Baik \\
14 & KS14 & 78 & 89,66 & Baik Sekali \\
15 & KS15 & 58 & 66,67 & Lebih dari Cukup \\
16 & KS16 & 59 & 67,82 & Lebih dari Cukup \\
17 & KS17 & 78 & 89,66 & Baik Sekali \\
18 & KS18 & 74,5 & 85,63 & Baik \\
19 & KS19 & 74 & 85,06 & Baik \\
20 & KS20 & 61,5 & 70,69 & Lebih dari Cukup \\
21 & KS21 & 66 & 75,86 & Lebih dari Cukup \\
22 & KS22 & 65 & 74,71 & Lebih dari Cukup \\
23 & KS23 & 47 & 54,02 & Hampir Cukup \\
24 & KS24 & 55,5 & 63,79 & Cukup \\
25 & KS25 & 73 & 83,91 & Baik \\
26 & KS26 & 72 & 82,76 & Baik \\
27 & KS27 & 69 & 79,31 & Baik \\
28 & KS28 & 72 & 82,76 & Baik \\
29 & KS29 & 82 & 94,25 & Baik Sekali \\
30 & KS30 & 58 & 66,67 & Baik Sekali \\
31 & KS31 & 78 & 89,66 & Baik \\
\hline & Jumlah & & $\mathbf{2 3 9 4 , 2 8}$ & $\mathbf{7 7 , 2 3}$ \\
\hline
\end{tabular}

Tabel 4.

Rentangan Nilai, Kualifikasi, Frekuensi, dan Persentase Kemampuan Mahasiswa setelah Menggunakan Model Group Investigation

\begin{tabular}{|c|c|c|c|c|}
\hline No & Rentangan Nilai & Kualifikasi & Frekuensi & Persentase (\%) \\
\hline 1 & $96-100$ & Sempurna & 0 & 0,00 \\
\hline 2 & $86-95$ & Baik Sekali & 7 & 22,58 \\
\hline 3 & $76-85$ & Baik & 9 & 29,03 \\
\hline 4 & $66-75$ & Lebih dari Cukup & 12 & 38,71 \\
\hline 5 & $56-65$ & Cukup & 1 & 3,23 \\
\hline 6 & $46-55$ & Hampir Cukup & 2 & 6,45 \\
\hline 7 & $36-45$ & Kurang & 0 & 0,00 \\
\hline 8 & $26-35$ & Kurang Sekali & 0 & 0,00 \\
\hline 9 & $16-25$ & Buruk & 0 & 0,00 \\
\hline 10 & $0-15$ & Buruk Sekali & 0 & 0,00 \\
\hline \multicolumn{3}{|c|}{ Jumlah } & 31 & 100 \\
\hline
\end{tabular}


Berdasarkan data pada Tabel 4, diperoleh gambaran kemampuan mahasiswa dalam menganalisis kasus pelangaran UU ITE setelah model GI sebagai berikut. Pertama, mahasiswa yang memperoleh nilai dengan kualifikasi Baik Sekali (BS) berjumlah 7 orang (22,58\%). Kedua, mahasiswa yang memperoleh nilai dengan kualifikasi Baik (B) berjumlah 9 orang $(29,03 \%)$. Ketiga, mahasiswa yang memperoleh nilai dengan kualifikasi Lebih dari Cukup (LdC) berjumlah 12 orang (38,71\%). Keempat, mahasiswa yang memperoleh nilai dengan kualifikasi Cukup (C) berjumlah 1 orang (3,23\%). Kelima, mahasiswa yang memperoleh nilai dengan kualifikasi Hampir Cukup (HC) berjumlah 2 orang (6,45\%). Selanjutnya, data kemampuan mahasiswa dalam menganalisis kasus pelangaran UU ITE setelah model GI dideskripsikan dalam bentuk diagram batang sebagaimana yang terlihat pada Gambar 2.

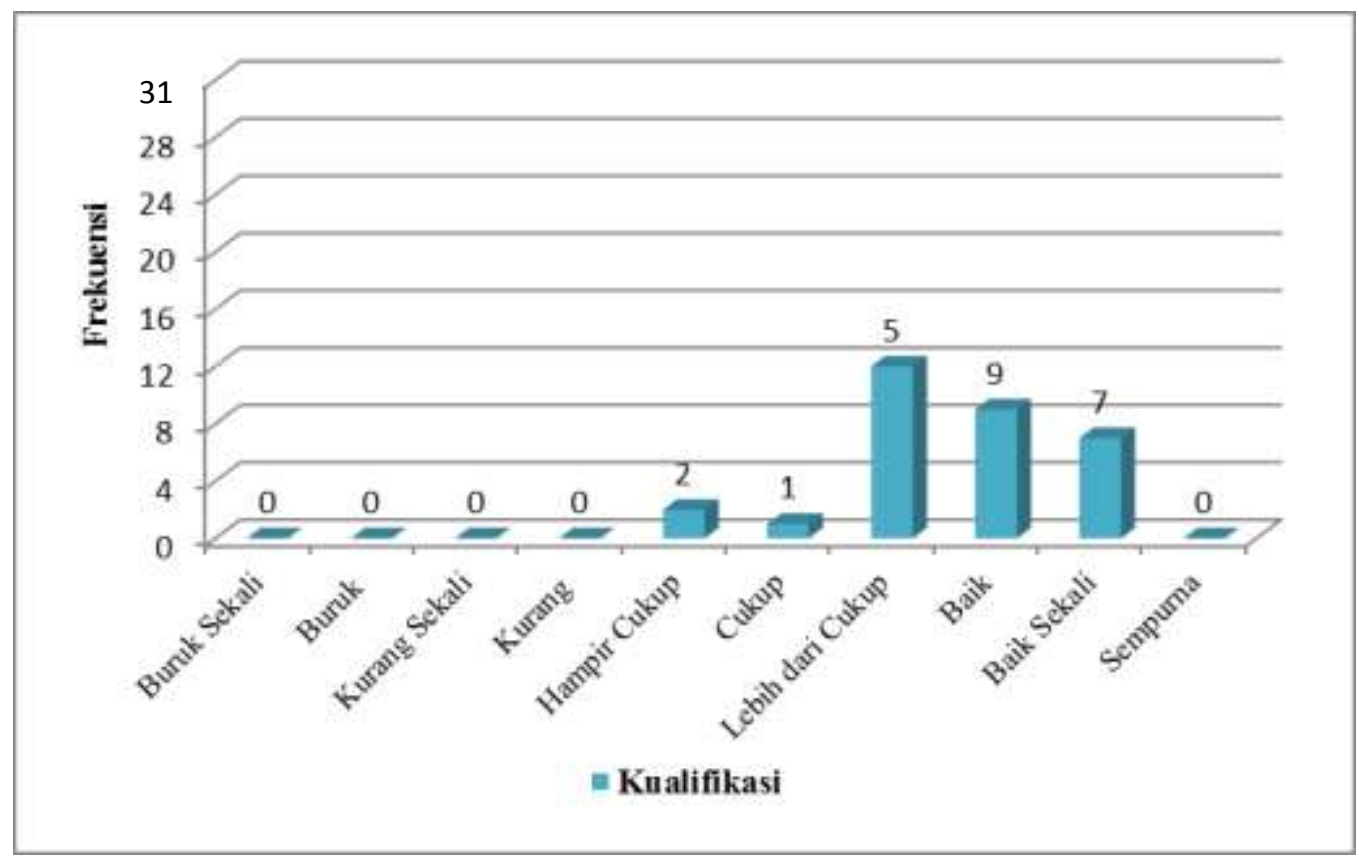

Gambar 2. Diagram Batang Kemampuan Mahasiswadalam Menganalisis Kasus Pelangaran UU ITE setelah Menggunakan Model Group Investigation

Perbandingan Kemampuan Mahasiswa dalam Menganalisis Kasus Pelangaran UU ITE sebelum dan setelah Menggunakan Model Group Investigation

Untuk menjawab hipotesis penelitian yang menyatakan bahwa ada atau tidaknya pengaruh model GI terhadap kemampuan mahasiswa dalam menganalisis kasus pelangaran UU ITE dapat diketahui dengan cara membandingkan kemampuan mahasiswa dalam menganalisis kasus pelangaran UU ITE sebelum dan setelah penerpan model GI. Untuk lebih jelasnya, perbandingan tersebut dapat dilihat pada Tabel 5.

Tabel 5.

Perbandingan Kemampuan Mahasiswa dalam Menganalisis Kasus Pelangaran UU ITE sebelum dan setelah Menggunakan Model Group Investigation

\begin{tabular}{ccccccc}
\hline No & $\begin{array}{c}\text { Kelompok } \\
\text { Sampel }\end{array}$ & $\sum \mathbf{X}$ & $\sum \mathbf{X}^{\mathbf{2}}$ & $\overline{\boldsymbol{X}}$ & $\boldsymbol{X}_{\text {maks }}$ & $\boldsymbol{X}_{\text {min }}$ \\
\hline 1 & Prates & 1806,31 & 3262755,82 & 58,27 & 78,16 & 41,38 \\
2 & Pascates & 2394,28 & 5732576,72 & 77,23 & 94,25 & 49,43 \\
\hline
\end{tabular}

Berdasarkan Tabel 5, dapat dilihat bahwa kemampuan mahasiswa dalam menganalisis kasus pelangaran UU ITE setelah menggunakan model GI (pascates) lebih besar dari kemampuan mahasiswa dalam menganalisis kasus pelangaran UU ITE sebelum menggunakan model GI (prates).

Uji Normalitas Data

Uji normalitas data dilakukan untuk mengetahui apakah data berdistribusi normal atau tidak. Uji normalitas data dilakukan dengan uji Liliefors. Berdasarkan uji normalitas yang dilakukan, diperoleh $\mathrm{L}_{0}$ dan $\mathrm{L}_{\mathrm{t}}$ pada taraf signifikansi 0,05 untuk $n=31$, seperti pada Tabel 6 . 
Tabel 6. Uji Normalitas Data

\begin{tabular}{ccccccc}
\hline No & Kelompok Sampel & Jumlah (N) & $\begin{array}{c}\text { Taraf } \\
\text { Nyata }\end{array}$ & $\mathbf{L}_{\mathbf{0}}$ & $\mathbf{L}_{\mathbf{t}}$ & Keterangan \\
\hline 1 & Prates & 31 & 0,05 & 0,018 & 0,161 & $\begin{array}{c}\text { Bertrisdibusi } \\
\text { Normal } \\
\text { Berdistribusi } \\
\text { Normal }\end{array}$ \\
\hline
\end{tabular}

Berdasarkan Tabel 6, disimpulkan bahwa data kelompok prates berdistribusi normal karena $\mathrm{L}_{0}$ kecil dari $\mathrm{L}_{\mathrm{t}}(0,018<0,161)$ pada taraf signifikansi 0,05 untuk $\mathrm{n}=30(\mathrm{n}-1)$. Demikian juga dengan data kelompok pascates yang berdistribusi normal karena $L_{0}$ kecil dari $L_{t}(0,078<0,161)$ pada taraf signifikansi 0,05 untuk $n=30(n-1)$.

\section{Uji Homogenitas Data}

Uji homogenitas data dilakukan untuk mengetahui apakah kedua kelompok sampel homogenitas atau tidak. Berdasarkan uji homogenitas data yang dilakukan, diperoleh $\mathrm{F}_{\text {hitung }}$ dan $\mathrm{F}_{\text {tabel }}$ pada taraf signifikansi 0,05 dengan $\mathrm{dk}=\mathrm{n}-1$, seperti pada Tabel 7.

Tabel 7. Uji Homogenitas Data

\begin{tabular}{ccccccc}
\hline No & Kelompok Sampel & Jumlah $(\mathbf{N})$ & $\begin{array}{c}\text { Taraf } \\
\text { Nyata }\end{array}$ & $\mathbf{F}_{\text {hitung }}$ & $\mathbf{F}_{\text {tabel }}$ & Keterangan \\
\hline 1 & Prates & 31 & 0,05 & 1,64 & 1,84 & Homogen \\
\hline
\end{tabular}

Dari Tabel 7, diperoleh $F_{\text {hitung }}=1,64$ yang lebih kecil dari $F_{\text {tabel }}=1,84$ pada taraf nyata $\propto=0,05$ dan $\mathrm{dk}=$ 30 (n-1). Oleh karena $\mathrm{F}_{\text {hitung }}<\mathrm{F}_{\text {tabel }}(1,64<1,84)$, disimpulkan bahwa data homogen.

\section{Uji Hipotesis}

Pengujian hipotesis dilakukan untuk mengetahui apakah ada atau tidaknya pengaruh model GI terhadap kemampuan mahasiswa dalam menganalisis kasus pelangaran UU ITE. Uji-t dapat dilakukan setelah diketahui bahwa kelompok data berdistribusi normal dan memiliki homogenitas. Langkah pertama yang dilakukan untuk uji-t adalah menentukan standar deviasi gabungan $\left(\mathrm{S}^{2}\right)$.

Diketahui standar deviasi gabungan $\left(\mathrm{S}^{2}\right)$, yaitu 102,02. Dengan demikian, dapat ditentukan perbandingan kemampuan mahasiswa dalam menganalisis kasus pelangaran UU ITE sebelum dan setelah menggunakan model GI dengan melakukan uji-t. Berdasarkan hasil uji-t, diperoleh $t_{\text {hitung }}=7,41$ (harga mutlak) yang lebih besar dari $t_{\text {tabel }}=1,70$ (terdapat pada Lampiran 25) pada taraf nyata $\propto=0,05 \mathrm{dan} d \mathrm{k}=30(\mathrm{n}-1)$. Oleh karena $\mathrm{t}_{\text {hitung }}$ $>t_{\text {tabel }}(7,41>1,70)$, disimpulkan bahwa hipotesis alternatif diterima. Dengan kata lain, penggunaan model GI berpengaruh secara signifikan terhadap kemampuan mahasiswa dalam menganalisis kasus pelangaran UU ITE. Hal tersebut juga terlihat dari rata-rata tes kemampuan mahasiswa dalam menganalisis kasus pelangaran UU ITE setelah menggunakan model GI (pascates) lebih tinggi dari rata-rata tes kemampuan mahasiswa dalam menganalisis kasus pelangaran UU ITE sebelum menggunakan model GI (prates).

Model Group Investigation dalam pembelajaran menganalisis kasus pelanggaran UU ITE adalah serangkaian kegiatan yang menekankan pada proses berpikir kritis dan sistematis sehingga mahasiswa mampu menganalisis bentuk pelanggaran dan mengaitkannya dengan pasal-pasal yang terdapat dalam UU ITE. Selain itu, mahasiswa juga diberi kesempatan untuk berkolaborasi antarteman dalam mengatasi permasalahan yang muncul dalam masyarakat terkait penggunaan teknologi informasi. Dengan begitu, model ini mampu memotivasi mahasiswa dalam mengikuti pembelajaran menganalisis kasus pelanggaran UU ITE dan mempunyai pengaruh dalam meningkatkan kemampuan Mahasiswa Jurusan Sistem Informasi STMIK Indonesia Padang dalam menganalisis kasus pelanggaran UU ITE. Hal ini dapat dibuktikan dengan jalan membandingkan perbedaan kemampuan menganalisis kasus pelanggaran UU ITE sebelum menggunakan model GI dan setelah menggunakan model GI sebagaimana berikut.

Pertama, nilai tertinggi yang diperoleh mahasiswa pada tes awal (prates) adalah 78, 16 dengan kualifikasi Baik (B), sementara nilai terendah yang diperoleh mahasiswa adalah 41,38 dengan kualifikasi Kurang (K). Rata-rata nilai kemampuan menganalisis kasus pelanggaran UU ITE sebelum menggunakan model GI adalah 58,27 dengan kualifikasi Cukup (C). Jika dibandingkan dengan nilai ketuntasan minimum yang ditetapkan, yaitu 76, rata-rata nilai kemampuan mahasiswa dalam menganalisis kasus pelanggaran UU ITE sebelum menggunakan Model GI dinyatakan belum tuntas. 
Kedua, nilai tertinggi yang diperoleh mahasiswa pada tes akhir (pascates) adalah 94,25 dengan kualifikasi Baik Sekali (BS), sementara nilai terendah yang diperoleh mahasiswa adalah 49,43 dengan kualifikasi Hampir Cukup (HC). Rata-rata nilai kemampuan mahasiswa dalam menganalisis kasus pelanggaran UU ITE setelah menggunakan model GI adalah 77,23 dengan kualifikasi Baik (B). Jika dibandingkan dengan nilai ketuntasan minimum, rata-rata nilai kemampuan mahasiswa dalam menganalisis kasus pelanggaran UU ITE setelah menggunakan model GI dinyatakan sudah tuntas atau sudah berada pada taraf di atas nilai ketuntasan minimum.

Berdasarkan hasil analisis data di atas, dapat dilihat perbedaan kemampuan mahasiswa dalam menganalisis kasus pelanggaran UU ITE sebelum menggunakan model GI dan setelah menggunakan model GI. Hal itu ditunjukkan oleh rata-rata nilai yang diperoleh pada tes akhir (setelah penggunaan model GI), yaitu 77,23 dengan kualifikasi Baik (B) yang jauh berbeda dengan rata-rata yang diperoleh mahasiswa pada tes awal (sebelum penggunaan model GI), yaitu 58,27 dengan kualifikasi Cukup (C).

Perbedaan rata-rata kemampuan mahasiswa dalam menganalisis kasus pelanggaran UU ITE sebelum dan setelah menggunakan model GI, dianggap sebagai pengaruh yang ditimbulkan oleh penggunaan model GI yang diberikan pada mahasiswa. Hal ini dikarenakan pada saat proses pembelajaran menganalisis kasus pelanggaran UU ITE dengan menggunakan model GI, mahasiswa termotivasi untuk mengikuti pembelajaran dan terlatih berpikir kritis dalam menemukan isi atau suatu permasalahan dengan mengambil posisi (sikap), serta mempertahankan sikap tersebut dengan argumentasi yang relevan dan valid.

Pembelajaran keterampilan menganalisis kasus pelanggaran UU ITE dengan menggunakan Model GI juga telah memberikan hasil yang positif dalam interaksi sosial, pemrosesan kelompok, dan tanggung jawab pada setiap kemampuan dalam kelompoknya masing-masing. Hal itu dapat terlihat dari banyaknya mahasiswa yang aktif terlibat dalam diskusi dan antusias dalam menjawab pertanyaan-pertanyaan yang diberikan, serta antusias dalam memberikan pendapat-pendapat dari hasil diskusi kelompoknya. Dalam pembelajaran ini mahasiswa diberi kesempatan untuk berkolaborasi antarteman dalam mengambil sikap untuk mengatasi permasalahan terhadap pelanggaran UU ITE sehingga pembelajaran menganalisis kasus pelanggran UU ITE menjadi suatu pembelajaran yang menyenangkan dan memberikan motivasi kepada mahasiswa.

Demikian juga halnya dengan hasil uji hipotesis yang telah dilakukan menunjukkan bahwa $t_{\text {hitung }}>t_{\text {tabel }}$ $(7,41>1,70)$ pada taraf signifikansi 95\%. Dengan demikian, disimpulkan bahwa penggunaan model GI mempunyai pengaruh yang signifikan terhadap pembelajaran kemampuan menganalisis kasus pelanggaran UU ITE. Hal ini dikarenakan, pembelajaran dengan menggunakan model GI dapat menjadikan mahasiswa saling berinteraksi dengan mahasiswa lainnya sehingga mahasiswa yang pandai dan mahasiswa yang kurang pandai dapat menyatukan pendapat. Hal ini sejalan dengan pendapat (Slavin, 2009) yang mengungkapkan bahwa pembelajaran kooperatif (termasuk pembelajaran dengan model GI) adalah metode atau model dimana peserta didik belajar bersama, saling menyumbangkan pikiran dan tanggung jawab terhadap pencapaian hasil belajar individu dan kelompok. Model pembelajaran GI merupakan model yang dapat mengembangkan keterampilan berpikir dalam kelompok-kelompok kecil yang memiliki kemampuan heterogen. Hal itu didukung oleh (Elaine B. Johnson, 2014) yang menjelaskan bahwa pembelajaran kooperatif adalah proses pembelajaran yang melibatkan penggunaan kelompok-kelompok kecil yang memungkinkan siswa untuk berkerjasama guna memaksimalkan pembelajaran mereka sendiri dan pembelajaran satu dengan yang lainnya. Artinya, mahasiswa dapat belajar dari mahasiswa lainnya dan tidak tergantung kepada dosen.

Berdasarkan hasil penelitian di atas dapat disimpulkan bahwa model GI dapat memberikan pengaruh yang positif terhadap peningkatan kemampuan mahasiswa menganalisis kasus pelanggaran UU ITE. Oleh karena itu, dosen pengampu disarankan menggunakan model GI sebagai pertimbangan dalam pelaksanaan pembelajaran menganalisis kasus pelanggaran UU ITE.

\section{KESIMPULAN}

Berdasarkan hasil analisis data dan pembahasan, disimpulkan tiga hal berikut. Pertama, kemampuan mahasiswa dalam menganalisis kasus pelangaran UU ITE sebelum menggunakan model GI berada pada kualifikasi Cukup (C) dengan nilai rata-rata 58,27. Jika dibandingkan dengan nilai ketuntasan minimum yang ditetapkan yaitu 65, rata-rata nilai kemampuan mahasiswa dalam menganalisis kasus pelangaran UU ITE sebelum menggunakan model GI dinyatakan belum tuntas. Kedua, kemampuan mahasiswa dalam menganalisis kasus pelangaran UU ITE setelah menggunakan model GI berada pada kualifikasi Baik (B) dengan nilai rata- 
rata 77,23. Jika dibandingkan dengan nilai ketuntasan minimum yang ditetapkan, rata-rata nilai kemampuan mahasiswa dalam menganalisis kasus pelangaran UU ITE setelah menggunakan model GI b dinyatakan sudah tuntas. Ketiga, berdasarkan hasil uji-t, diperoleh $t_{\text {hitung }}>t_{\text {tabel }}(7,41>1,70)$ pada taraf signifikansi $95 \%$. Dengan demikian, disimpulkan bahwa penggunaan model GI mempunyai pengaruh yang signifikan terhadap kemampuan mahasiswa dalam menganalisis kasus pelangaran UU ITE.

Berdasarkan simpulan di atas, diajukan dua saran berikut. Pertama, disarankan kepada Dosen Mata Kuliah Etika Profesi untuk lebih memvariasikan model pembelajaran, khususnya dalam pembelajaran menganalisis kasus pelanggaran UU ITE, yaitu dengan menggunakan model GI. Hal ini dikarenakan model GI dapat membuat mahasiswa berinteraksi dengan mahasiswa lainnya sehingga mahasiswa yang pandai dan mahasiswa yang kurang pandai dapat menyatukan pendapat. Disamping hal tersebut, juga disarankan kepada dosen untuk lebih memperhatikan motivasi belajar mahasiswa sebelum pelaksanaan pembelajaran karena perbedaan motivasi belajar yang ada pada diri mahasiswa juga akan membedakan cara atau model belajar siswa. Dengan adanya pengetahuan awal tentang motivasi belajar mahasiswa, maka dosen dapat menentukan model pembelajaran mana yang sesuai dengan kebutuhan mahasiswa. Model pembelajaran yang dipilih sebaiknya dapat mengembangkan motivasi belajar mahasiswa terhadap pembelajaran menganalisis kasus pelanggaran UU ITE. Kedua, disarankan kepada mahasiswa Jurusan Sistem Informasi STMIK Indonesia Padang agar lebih memahami dan menguasai UU ITE, serta melatih diri untuk lebih berpikir kritis dalam memberikan penilaian dan analisis terhadap sebuah kasus pelanggaran UU ITE.

\section{UCAPAN TERIMA KASIH}

Terima kasih kami sampaikan kepada STMIK Indonesia Padang Yayasan Amal Bakti Mukmin Padang yang telah membiayai pelaksanaan kegiatan ini dengan nomor kontrak: 026/K.A/LPPM/STMIK-I/2018, serta kepada semua pihak yang telah membantu pelaksanaan kegiatan penelitan ini.

\section{REFERENSI}

Atmaja, A. E. (2014). Kedaulatan Negara di Ruang Maya: Kritik UU ITE dalam Pemikiran Satipto Rahardjo. Jurnal Opinio Juris, 16(Mei-September), 48-91. Retrieved from https://pustakahpi.kemlu.go.id/app/ Kedaulatan Negara di Ruang-maya Kritik UU ITE dalam Pemikiran Satjipto Rahardjo - AP Edi Atmaja.pdf

Elaine B. Johnson. (2014). Contextual Teaching dan Learning: Menjadikan Kegiatan Belajar-Mengajar Mengasyikkan dan Bermakna Terjemahan oleh Ibnu Setyawan. Bandung: MLC.

Perwitasari, V. R. S., Sumarmi, \& Amirudin, A. (2016). Pengaruh Group Investigation Berbasis Outdoor Study terhadap Kemampuan Berpikir Analitis Siswa. Jurnal Pendidikan: Teori, Penelitian, Dan Pengembangan, 1(3), 87-93.

Slavin, R. E. (2009). Cooperative Learning: Teori, Riset dan Praktik. Bandung: Nusa Media.

Wijayanti, A. P., Sumarmi, \& Amirudin, A. (2016). Perbandingan Model Group Investigation dengan Problem Based Learning Berbasis Multiple Intelligence terhadap Kemampuan Memecahkan Masalah Siswa SMA. Jurnal Pendidikan: Teori, Penelitian, Dan Pengembangan, 1(5), 948-957. 